\title{
Control of Hydrogen Sulphide Formation and Enhancement of the Ethanol Yield in Coconut Toddy - Field Trials
}

\author{
A. W. LIYANAGE, D. J. ABEYRATNE, M. R. HETTIARACHCHI, \\ K. D. L. GUNATILAKE, G. G. WEERAWANSA AND P. M. JAYATISSA
}

Industrial Microbiology Section, Ceylon Instirute of Scientific and Industrial Research, P.O. Box 787, Colombo 7, Sri Lanka.

(Date of receipt: 14 May 1982)

(Date of acceptancé: 19 January 1983.)

\begin{abstract}
Field trials were carried out to test the finding that tbe addition of a m monium sals, as a source of nitrogen for the metabolism of toddy yeast, suppressos completely the formation of hydrogen sulphide and enhances the etbanol yields. Foup field trials carried out, under normal conditions of tapping, showad that the addition of ammonium sajts at a concentration of $0.08 \%(\mathrm{w} / \mathrm{v})$ of $\mathrm{NH}_{4}^{+}$ions to the collection pot prior lo tapping increased ine ethanol content of toddy by an average of $12.5 \%$ a od the cola vield of elhanol by a a verage of $26.5 \%$. At this concentration of $\mathrm{NH}_{4}^{+}$ions the formation of hydeogen sulphide was atso completely suppressed. Statistical analysis showed that the results observed are of higr statistical significance.
\end{abstract}

\section{Introduction}

Coconut palm wine (toddy) is a traditional beverage of Sri Lanka and other coconue growing countries. Toddy is the fermented sap of the young inflorescence of the coconut palm (Cocos nucifera). The unfermeneed sap (sweel loddy) is the exudate obtained from the young inflorescence by subjecting it 10 a skijied process called tapping. The unfermented sap contains aboue $15-20 \%$ (w/v) sugars (mainly sucrose) which are fermented to ethanol and a number of minor componenes by a mixcure of wild yeast and bacteria. The fermented coconue palm wine which contains aboue $7 \%$ $(v / v)$ ethanol is drunk fresh or bottled (pasteurized) or is distilled to produce a palm brandy (arrack).

The natural fermentation of toddy caused by the various cypes of wild yeast and bacteria produces not only ethanol but also many by-products. The formation of these by-products is responsible for the low ethanol yields and the off-flavours of coconue toddy: $y_{2}^{\prime 2}$ It has been reported that the ethanol content of naturally [ermented coconut toddy is about $30 \%$ less than the theoretical yield. 
The main contributory factor for the off navour of coconut toddy has been traced to the formation of hydrogen sulphideduring the natura'fermentation. Janszet al. who earried out a detailed study on this'subject attributed the formation of hydrogen sulphide in toddy to the metabolic activities of some wild yeasts where the sulphur containing amino acid cysteine is utilized with the release of hydrogen sulphide. The mechanism of this process as proposed by Hough et al' is given in figure 1 .

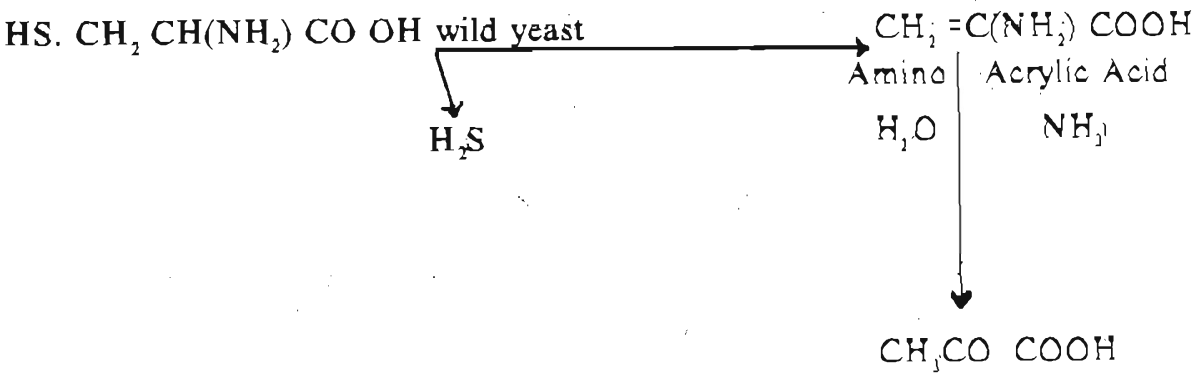

Figure 1. Cysteine metabolism by yeast.

Subsequent work on the control of hydrogen sulphide formation in toddy carried out by Jansz et al and Kalyananda ef ala resulted in the discovery of a number of methods for this purpose. Out of these ruethods the addition of small amounts of ammonium salts to the sweet toddy before the commencement of the fermentation process appeared to be the simplest and the most feasible on a commercial scale. The most attractive feature of this process was the increase in the elbano yield in the resulting toddy, which was around $25 \%{ }_{-}^{4}$

Though coconut toddy has been a popular alcoholic beverage for several centuries and also served as the base for toe distillation of coconue arrack, the problems of undesired flavours and low ethanoi yields have remained unsolved. The methods reported earlier such as the use of pure culeure fermentacion for increasing the ethanol yield sogre impracticable on a commercial scaie. Therefore, the findings of Jansz et al and Kalyananda et al ${ }^{4}$ after excensive research were considered 10 be of paramount importance to the coconut toddy ind ustry in solving the above mentioned problems.

These findings were important as they indicated that the low yields of ethanol and off flavour of coconut toddy could be solved by the simple operation of adding ammonium salts to the collecting pot during the normal tapping process used on a commercial scale. 
The field trials reported in this paper were ca ried out to test the ap picabiuty of these findings on a commercial scale. A detailed accounc is presented of four.field trials carried out in four different locations and a statistical analysis of the results.

\section{Experimental}

\subsection{Tapping and Fermentation of Coconut Toddy}

Tapping of coconut palms for toddy was carried ou by the regular tappers using the normal tapping procedure and schedule. The tota! number of coconut palms in each field trial were grouped into batches for convenience, and one sample $(200 \mathrm{~m})$ from each batch was drawn for analysis. Control (without added NHJ and experimeata: (with added $\mathrm{NH}_{4}^{+}$)trials were carried out on alternate days. The same coliection pot was used for both the control and the experimentaltrials for each inforescence. In the experimental trials a calculated amount of ammonium chorice was added (as a. solution or in the form of tablets) to the collecting pot at the time of tapping. Each ammonium chloride tablet weighed about $0.6 \mathrm{~g}$ and contained $0.20 \mathrm{~g}$ of $\mathrm{NH}$. The amount of ammonium chloride to be added was calculated based on the volume of toddy collected on the previous day. The number of tablets added was one for every $250 \mathrm{ml}$ of toddy. The volume of toddy collected per pot ranged from $250 \mathrm{~m} / 102000 \mathrm{~m}$ !. In order to complete the fermentation, toddy samples collected 24 hours after tapping were allowed to stand for another $8-10$ hours before anajysis. However the evolution of hydrogen sulphide was monitored right from the time the samples were collected ie. from $8.00 \mathrm{a} . \mathrm{m}$. to $3.00 \mathrm{p} . \mathrm{m}$. on the same day of colsection.

\subsection{Analytical Methods}

2.2.1 Estimation of Ethyl Alcohol - The ethyl alcohol contene of samples of toddy was estimated by the use of an Ebulliometer and was expressed as a percentage by volume.

2.2.2 Estimation of Residual Sugar - The total residual sugar after inversion was estimated by the Lane and Eynon meth od and was expressed as a perceneage by weight. 
2.3 Detection of Hydrogen. Sulpkide - Hydrogen sulphide was defected qualitatively by the use of lead-acetate paper.

2.4 Ammonium chloride powder (technical grade) was obtained from British Drug House Limited, Overseas Division, U.K.

\section{Results}

3.1 Field trials Ia and 1 b - Conducted at the Bandirippuwa Estate Coconut Research Institute Lunuwila (From 15th March to 20th March 1978)

For these field trials a total number of seventy seven (77) trees were used, which were grouped into 9 batches. The effect of adding $\mathrm{NH}_{4}^{*}$ on the yield of ethanoi and the formation of hydrogen sulphide was studied using two concentrations of ammonium chloride. The ammonium chloride was added in the form of a solution and the two concentrations used were $0.05 \%(\mathrm{w} / \mathrm{v})$ and $0.08 \%(\mathrm{w} / \mathrm{v})$ of $\mathrm{NH}_{4}^{+}$based on the voiume of toddy.

The results of this field trial are given in Table 1.

Incorporation of $\mathrm{NH}_{4}^{+}$at a concentration of $0.05 \%$ (w/v) only partly suppressed the formation of hydrogen sulphide. In some batches there was no suppression at all. However, the ethanol yield was found to increase appreciab!y and the results showed an average increase of $28 \%$ in total yield of ethanol per batch and an average increase of $13.0 \%$ in the ethanol content of the toddy. With the increase of the $\mathrm{NH}_{4}$ concentration to $0.08 \%(\mathrm{w} / \mathrm{v})$ a complete suppression of the hydrogen sulphide formation was observed in all batches. At the same time the cotal yield of ethanol per batch increased by an average of $46 \%$ while the ethanol concene in toddy increased by an average of $32 \%$. The residua! sugar conenes of fermented toddy was found to be very much less in samples treated with $\mathrm{NH}_{4}^{+}$(at both concentrations) as compared with untreated (control) samples

3.2 Field Trial 2 - Conducted at the Galawatte Estate, Land Reform Commission, Bandirippuwa (From 13th February to 20th Febraary 1979)

In this field trial, ammonium chloride was incorporated into toddy in the form of tablets to give the required concentration of $\mathrm{NH}^{\circ}$ ions. The conceneration of $\mathrm{NH}$;ions used was $0.08 \%(\mathrm{w} / \mathrm{v})$ based on the volume of loddy expected. The results are given in table 1. 


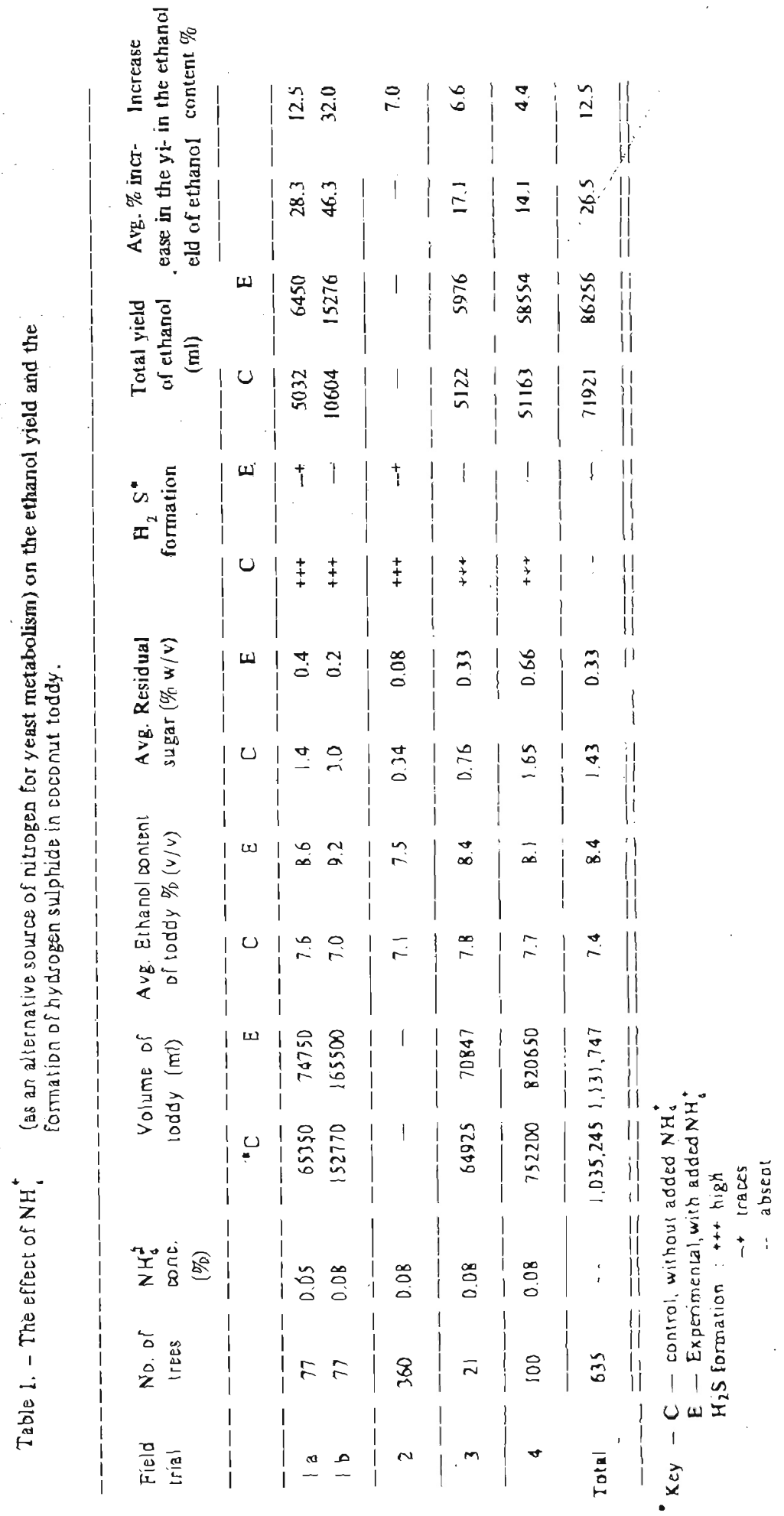


Three hundred and twenty four (324) trees were used in this trial which were grouped into nine batches. In this trial the effect of adding $\mathrm{NH}_{4}^{*}$ ions on the echanol content of the toddy and the formation of hydrogen suphide was studied. The effect of $\mathrm{NH}_{4}^{+}$on the total yield of ethanol per batch was not studied.

The results showed that the suppression of the formation of hydrogen sulphide in the $\mathrm{NH}_{4}^{+}$treated samples was not complete and aiso the increase in the ethannl content of toddy was around $7 \%$.

The results of this field trial was affected by the changing weather conditions mainly by the intermittent fall of rain.

3.3 Field Trial 3 - Conducted at the Kiripallagahawatte Estate, Molligoda, Wadduwa (From 30th November to 5th December 1979)

In this field trial, $\mathrm{NH}_{4}^{+}(0.08 \% \mathrm{w} / \mathrm{v})$ were added to the pot in the form of $\mathrm{NH} . \mathrm{Cl}$ tablets as in the case of the 2 nd field trial. The results are given in Table $:$.

At this concentration of $\mathrm{NH}_{4}^{+}$in the toddy an average increase of $17.1 \%$ in the total yield of ethanol per batch and an average increase of $6.6 \%$ in the ethanol content of the toddy was observed. In addition the hydrogen sulphide formation in toddy was also completely suppressed.

\subsection{Field Trial 4-Conducted at the Molligoda Estale, Molligoda, Wadduwa (From 29th October to 7th November 1980)}

In this field trial too $\mathrm{NH}_{4} \mathrm{Cl}$ was added to the pot in the form of tablets to give a concentration of $0.08 \%(\mathrm{w} / \mathrm{v})$ of $\mathrm{NH}_{4}^{+}$based on the cxpected yield of coddy. As a result, an average increase of $14.1 \%$ in the total yield of echanol per batch and an average increase of $4.4 \%$ in the ethanol content of the coddy were observed. The hydrogen sulphide formation in toddy was also completely suppressed (Table l).

\subsection{Statistical Analysis of the Results}

A statistical analysis of the results obtained with respect to the total yield of echanol and the ethanol content of toddy is given in Table 2. The average increase in the cotal yield of ethanol and the ethanol content of the toddy were statisticaily a nalysed to determine the significance of the observed increases. In this analysis the 'Pairedsample Test' was applied. This analysis showed that the observed mean increases in both the ethanol content of toddy and the total yield of ethanol were very highly significant. 


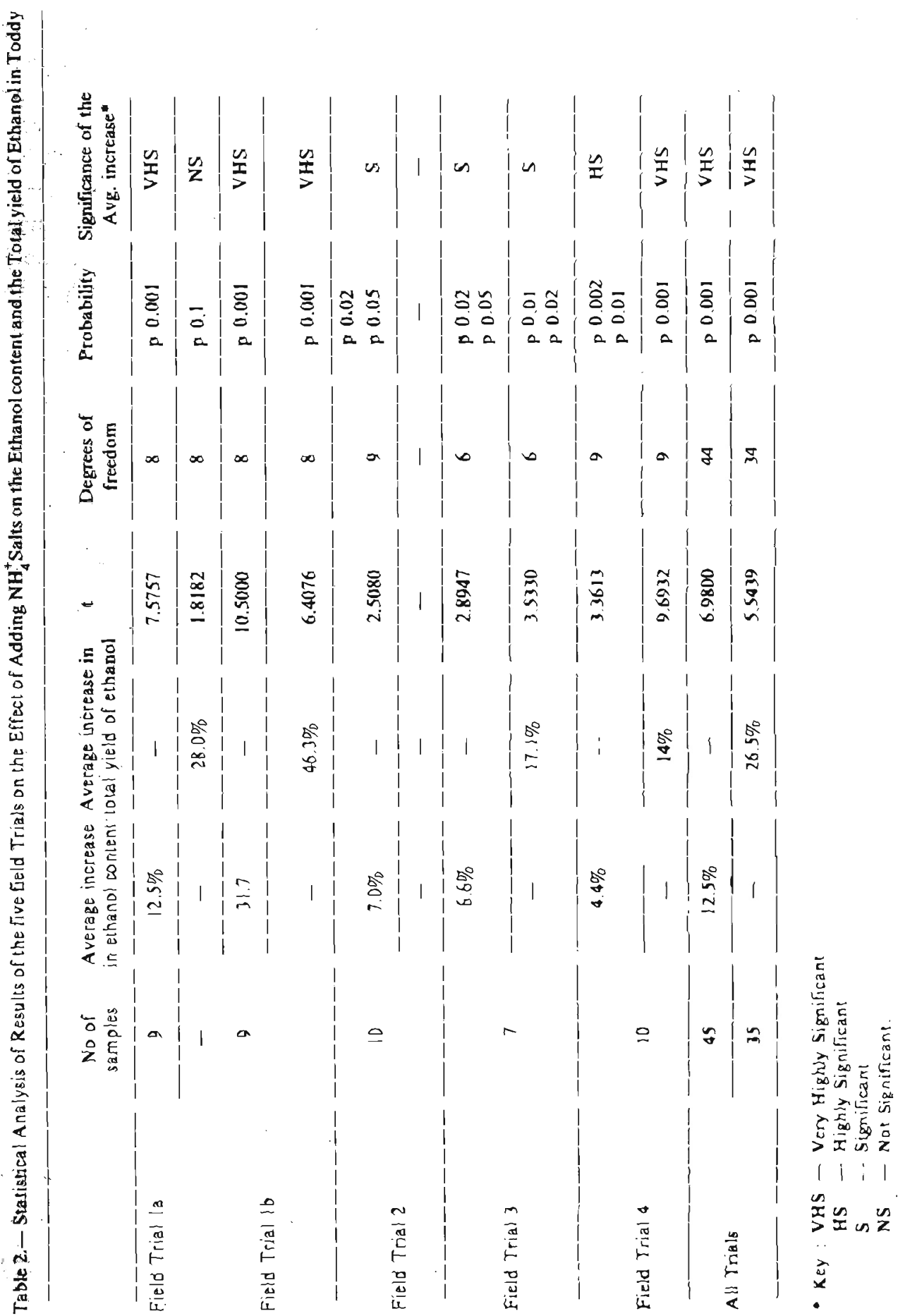


A tu Lljollage ef af

\section{Discusion}

In the natural fermentation of coconut toddy if appears thatorganic nitrogen in the form of amino acids acts as the main source of nitrogen for the yeast metabolism: During the utilization of cysteine hydrogen satphide is formed as a by-product which contaminates both toddy and the distilled prodtret Arrack grving rise to off-flavours. Furthermore, the ethanol yields obtained by the naturalfermentation are usually far below the theoretical yields. The low efficiency of Mgar utilization under noma? conditions appears to be the main reason for this which is apparent by the high residual sugar contents observed. The supply of a n alternative and an easily digestible source of nitrogen in the form of $\mathrm{NH}_{4}^{+}$, as recommended by Jarrsz et al appears 10 suppress the utilization of amino nitrogen by the wild yeast. As a resultibe formation of hydrogen sulphide is avoided, and the utilization of sugar is increased resulting in higher yields of ethanol.

In the field trials carried out to test this finding on a commercial scale as reported in this paper a mean increase of $26.5 \%$ in the total vield of ethanol and a mean increase of $12.5 \%$ in the ethanol content were observed. The significance of these increases on statistical evaluation showed to be very high. It was necessary in this study to express the increases in the ethanol yields in cerms of both the total yield per field trial and the percentage ethanol content of the toddy. This was because the percentage ethanol content itself was inadequate to give a true picture due to dilution of the toddy by rain water on many occasions.

The high statistical significance of the observed trends in these experiments are important when the highly variable experimenta: conditions under which the field trials were conducted are considered. The higher increases in the alcohol yields observed in trials la and particularly in $1 \mathrm{~b}$ may be auributed to the use of ammonium chloride in the form of a solution in these rials. However, coraparative studies on the solubility and mixing of ammonium chloride in the coddy, when it is used as a solutian or as a tablet, revealed that even in the form of a tablet a mmonium chloride dissolved and mixed adequately in the toddy. Some of the main problems encouncered in this study were:

(a) Inaccuracies caused by uneducated tappers in the estimation of the number of tablets or the volume of solution of $\mathrm{NH}_{4} \mathrm{Cl}$ to be added to the collection pot on the basis of the expected volume of coddy.

(b) Adverse weather conditions mainly rainfall, which cause variation of sugar content of the sap, dilution of the codds. etc. 
The most attractive feature of the findings of this study is the financiai benerits that could be achieved by the commercial implementation of the process. From preliminary calculations it has been shown that the successiu: commercia: implementation of this process would bring about the foltowing

(a) An increase of 0.36 million proof gallons of ethano: per annum from the coconut toddy based distillation industries in Sri Lanka.

(b) A saving of Rs. 6.2 millions per annum in foreign exchange spent for the import of potable spirit.

(c) An increase of Rs. 6,350/-per annum per acre in the income from coconut toddy production.

The above figures were calculated on the following data and assumpcions:

(i) Total production of coconut spirits/annum $=1.47$ million proof gallons

(ii) Increase in the ethanol yield by the use of the reported

$$
\text { process }=25 \%
$$

(iii) Total imports of rectified spirits $=1.5$ million proof gallons $/$ year (at the cost of Rs. 22/-per proof gallon)

(Iv) Approximate volume of toddy/acre/day $=96$ litres

price of $\mathrm{NH}_{4} \mathrm{Cl}$ (Technical)/kg - Rs. 12.00

Cost of $\mathrm{NH}_{4} \mathrm{Cl}$ tablets/acre/day $=$ Rs. 6,60

Price of a gallon of coconut toddy (7\% v/v alcohoi): Rs. 6.00

\section{Refetences}

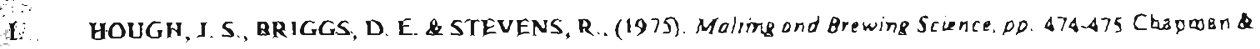
Hall Led.

2. JANSZ, E. R, JEYARA.J, E. E.. ABEYRATNE, D. J. \& PREMARATNE, 1. G.. (1979). J. Voin.Sci. COun. Sri Lanka, 3 (1) 1.

3. KALYANANDA. M. K. G. S., (19m7). Some aspecis of the fermenialion of coconut 1oddy. M. Sc. Thesis. University of Sri Lanka. Colombo. Sri Lonka.

4. Kalyananda, M. K. G. S. Jeyara. E. E. Jansz. E. R.. (1977). Proc. Inst. Chem.. Sri Lankd, Ann. Sess.

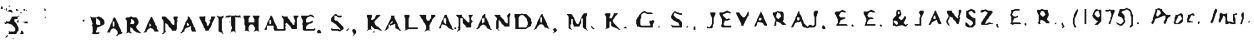
Chem., Sri Lanko. Ann. Sess.

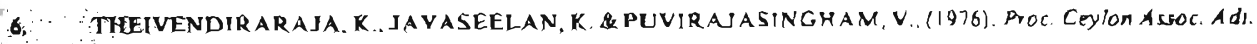
Suli, Sri Lanka. 